Human Ethology Bulletin 32 (2017)2: 1 - 4

Letter from the Editorial Board

\title{
Passing On The Chair
}

\section{Elisabeth Oberzaucher}

\author{
Editor in Chief
}

When I took over as editor in chief five years ago, the Human Ethology Bulletin had just undergone its metamorphosis from a newsletter of the International Society for Human Ethology into a peer reviewed online journal.

The possibilities of electronic communication and the Internet allowed for a transfer of society-related information to e-mails and a cost efficient production of an open access journal. This transition started with Aurelio Jose Figueredo as editor in chief and the help of a motivated team of associate editors, who were united from the beginning in the desire to create an outlet for ethological research that was barrier free, coming at no costs to author and reader. The strong belief in open access has been made possible through the financial support of ISHE, who covers the costs for editing and online hosting.

It is a long way from the decision to have a regular publication to the actual establishment of a journal. As in many scientific areas, there is no way for a butterfly to emerge from the cocoon without the help of countless dedicated scientists, whose vision fuels them in their pursuit of an idealistic goal. First and foremost the editorial team who not only handle the review process in order to ensure the scientific quality of the publication, but play a central role in publicising it through word of mouth, are the backbone of any scientific journal. Glenn E. Weisfeld, T. Joel Wade, Ian Stephen, Nancy L. Segal, Susanne F. Schmehl, Craig Roberts, John Richer, Iris J. Holzleitner, Colin Hendrie, Jan Havlicek, Glenn Geher, Maryanne Fisher, Aurelio Jose Figueredo, Martin Brüne, Louise Barrett and Thomas Alley (in reverse alphabetic order) with their diverse scientific backgrounds and interests represent what HEB is about: A scientific journal with high standards focussed on human behaviour. 
The large number of anonymous reviewers whose expertise and careful evaluation of the submissions guarantee that we are able to fairly assess the scientific quality of the submissions. The combined expertise of the entirety of the editorial board and the body of reviewers is important for any journal, but even more so for a journal that publishes in a cross-disciplinary field like HEB. Maybe most important is the role of the authors who have honoured HEB with their trust in the early days, enabling us to establish a continuous flow of publications.

In the course of the last five years, I worked with four different book review editors, whose contributions were invaluable for HEB: I want to express my thanks to (in oder of appearance) Iris Holzleitner, Maryanne Fisher, Kraig Shattuck and our current book review editor, Amanda Hahn.

HEB does not only publish its regular issues, but also special issues of two kinds: Themed special issues are constituted of a number of contributions around a specific theme. Craig Roberts served as editor for the special issue on Tinbergen celebrating the 50th anniversary of the publication of the seminal paper "On aims and methods in ethology".

Beginning with 2014 HEB publishes a special issue on the proceedings of ISHE's annual scientific meetings. Daniel Kruger served as editor for the proceedings of the 2013 summer institute in Ann Arbor that were published mid-2014. The 2014 conference in Belem, Brazil resulted in an excellent special issue co-edited by the ISHE couple Marco Antonio Correa Varela \& Jaroslava Varella Valentova that was published mid-2015. Susanne Schmehl served as editor for the proceedings of the 2015 Athens summer institute that were published early 2016. Finally, Caroline Allen edited the proceedings of the 2016 conference in Stirling that were published early in 2017. The proceedings issues are a beautiful documentation of what happens at the meetings, and serve to attract scholars to attend meetings for the first time (references).

Once a manuscript is accepted, the production team ensures that the scientific content is presented in an appropriate way. Thanks to Alexandra Mühlhauser, Susanne Schmehl and Kathrin Masuch, who have contributed at different stages to the conversion of manuscripts into proper articles.

The technical procedures behind the scenes kept us busy throughout the years. After encountering issues with our initial platform, we moved on to a different submission system and integrated the journal website more closely into the society website. As of now, all articles have a DOI and the references adhere to the cross-ref guidelines. Please use the DOIs to link to your articles rather than sharing the PDFs of your papers, this ensures the most sustainable access to your publication, as the DOI allows for individual identification of documents, irrespective of the location.

The metamorphosis of HEB from being a beautiful caterpillar mainly used for the internal communication of society-relevant news within the International Society for Human Ethology and launching the flight of the butterfly in form of an open access peer reviewed journal has been facilitated through many individuals, serving as enzymes, hormones and 
nutrition. Now that the wings of the butterfly are fully expanded and the flight movements have stabilised, it is time for me to pass the helm on to a new captain. Colin Hendrie has agreed to take over as editor in chief of the Human Ethology Bulletin and I am sure he will steer the journal towards excellent waters.

I look back at five years full of hard work and great joy and a grateful for the opportunity granted to me by ISHE. Thank you all for your substantial investments in the cooperative breeding effort!

Now, I pass the ball to Colin.

\section{REFERENCES}

Barret, L. \& Stulp, G. (2013). Four more reasons why ethology matters: Tinbergen and the human sciences. Human Ethology Bulletin, 28(4), 39-49

Dávid-Barrett, T., Rotkirch, A., Carney, J., Behncke Izquierdo, I. (2015). Mating strategies in Mozart's Figaro. Human Ethology Bulletin, 30 (1), 82-97.

Fernandez, A. M., Muñoz, J. A., Dufey, M., Pavez, P., Baeza, C. G., \& Kinkead, P. (2015). Sex differences in jealousy are not explained by attachment style in men and women from Chile. Human Ethology Bulletin, 30(1), 138-150.

Fisher, M. L. (2013). Tinbergen's influence on advances in female intrasexual competition research. Human Ethology Bulletin, 28(4), 23-30.

Fisher, M.L. \& Radtke, S. (2014) Sex Differences in Topics of Bathroom Graffiti. Human Ethology Bulletin, 28(2), 68-81.

Fisher, M. L. (2015). Women's competition for mates: Experimental findings leading to ethological studies. Human Ethology Bulletin, 30 (1), 52-69.

Fisher, M.L., Burch B. \& R.I. Sokol-Chang (2017). A Theoretical Proposal for Examining the Integration of Cooperative and Competitive Mothering Behavior. Human Ethology Bulletin, 32(1), 6-16. DOI

Hladký, V. \& Havlíček, J. (2013). Was Tinbergen an Aristotelian? Comparison of Tinbergen's Four Whys and Aristotle's Four Causes. Human Ethology Bulletin, 28(4), 3-11

Hinshaw, J.H. (2014). The Costs of Union Leadership. Human Ethology Bulletin, 28(2), 56-67.

Kruger, J. D., Fisher, M. L., De Backer, C., Kardum, I., Tetaz, M., \& Tifferet, S. (2015). Human life history dimensions in reproductive strategies are intuitive across cultures. Human Ethology Bulletin, 30 (1), 108-119.

Kruger, D.J., Day, M., Duan, A., Heyblom, A., Juhasz, D., Misevich, S., Phaneuf,C., Saunders, C., Sonnega, P. \& Sreenivasa, V. (2017). Understanding Variation in Reactions to Displays of Allegiance. Human Ethology Bulletin, 32(1), 17-28. DOI

Köster, M., Schuhmacher, N., \& Kärtner, J. (2015). A cultural perspective on prosocial development. Human Ethology Bulletin, , 30 (1), 70-81. 
Low, B.S. (2014). the Behavioural Ecology of Resource Consumtion: Why Being Green is So Hard. Human Ethology Bulletin, 28(2), 3-26.

McGrew, W. (2015). The cultured chimpanzee: nonsense or breakthrough? Human Ethology Bulletin, $30(1), 40-51$.

Mendonça, J. S., Bussab, V. S. R., Lucci, T. K., \& Kärtner, J. (2015). Father-child interactional synchrony in Brazilian families with maternal depression. Human Ethology Bulletin, 30 (1), 120-137.

Mikolić, A. (2016). Disgust and Facial Expression Recognition Across the Menstrual Cycle. Human Ethology Bulletin, 31(1), 60-73. DOI

Ottoni, E. B. (2015). Tool use traditions in nonhuman primates: the case of tufted capuchin monkeys. Human Ethology Bulletin, 30 (1), 21-39.

Pollet, T. \& Little, A.. (2017). Baseline Probabilities for Two-Alternative Forced Choice Tasks When Judging Stimuli in Evolutionary Psychology: A Methodological Note. Human Ethology Bulletin, 32(1), 53-59. DOI

Richer, J. (2014). “Disordered” Behaviour. Alternatives to DSM-5 from an Ethological Perspective. Human Ethology Bulletin, 28(2), 27-55.

Roberts, S.C. \& Eryaman, F. (2017). Mutual Olfactory Recognition Between Mother and Child. Human Ethology Bulletin, 32(1), 42-52. DOI

Seghers, E. (2016) Proximate and Ultimate Factors in Evolutionary Thinking on Art. Human Ethology Bulletin, 31(1), 47-59. DOI

Segerstrale, U. (2015). Science as adventure: The creative life of Bill Hamilton. Human Ethology Bulletin, 30 (1), 6-20.

Sharp, M. \& Hamilton, G. (2017). Female Gaze Behavior, Status and Menstrual Cycle: An Exploratory Study. Human Ethology Bulletin, 32(1), 29-41. DOI

Sloan Kruger, J., Castor, T., Kruger, D.J. (2016). Caffeine and Calorie Consumption at a College Campus Coffee Café. Human Ethology Bulletin, 31(1), 74-83. DOI

Stephen, I. D. (2013). On aims and methods of facial attractiveness research: The lasting influence of Tinbergen (1963). Human Ethology Bulletin, 28(4), 31-38

Sütterlin, Ch. (2016). Universals in Ritualized Genital Display of Apotropaic Female Figures. Human Ethology Bulletin, 31(1), 30-46. DOI

Weisfeld, C. C. \& Weisfeld, G. E. (2013). Defining normal on the playground: What would Tinbergen do? Human Ethology Bulletin, 28(4), 12-22.

Weisfeld, G. \& Cronin Weisfeld, C. (2016). Is Play an Emotion? Some Ethological Observations. Human Ethology Bulletin, 31(1), 4-29.. DOI

Wesselmann, E.D., Williams, K.D. \& Wirth, J.H. (2014). Ostracising Group Members Who Can (Or Cannot) Control being Burdensome. Human Ethology Bulletin, 28(2), 82-103.

Wlodarski, R., \& Dunbar, R. I. M. (2015). Are within-sex mating strategy phenotypes an evolutionary stable strategy? Human Ethology Bulletin, 30 (1), 98-107. 